\title{
COMPETENCE OF PRIMARY SCHOOLS IN THE PREVENTION OF RISK BEHAVIOUR - SCHOOL PREVENTION METHODOLOGIST
}

\author{
Lucie Blaštíková, Jitka Skopalová, Jan Zelinka
}

\begin{abstract}
The article deals with the issues of primary prevention of risk behaviour both on the theoretical and on the empirical plane. It focuses on the forms of manifestations of risk behaviour of second stage primary school pupils in selected schools of the Olomouc Region and on the methods and instruments which the schools use to prevent and address these manifestations. Under prevention, we understand the professional application of procedures to reduce the occurrence of and to prevent the spread of risk behaviour in schools and school facilities among children, pupils and students. These do not always connote specific interventions. Preventive measures can be understood as educational exposure to the development of positive social behaviour and communication, psychosocial skills and the leadership to an overall healthy lifestyle, accompanied by growing resistance to the negative phenomena which the pupils can and do encounter.
\end{abstract}

\section{Keywords}

primary school, prevention of risk behaviour, school prevention methodologist

\section{Introduction}

The topic of primary prevention is vast and lively, with a number of topical fields and contexts. In the text, we have tried to reflect on essential facts. School prevention works on both the horizontal and vertical levels, and the number of entities involved is quite extensive. On the horizontal level, the structures involve, in addition to representatives of most ministries, also representatives of non-governmental organizations, universities, professional and trade union associations or organizations directly subordinate to the Ministry of Education, Youth and Sports of the Czech Republic (henceforth MEYS). The vertical level is then formed by a hierarchical network of prevention methodologists and workers in schools and school facilities. They are the effective implementers of prevention in the school environment, they performs many tasks of all practical, administrative and conceptual nature. The current prevention concept is entitled "Národní strategie primární prevence rizikového chování dětí a mládeže na období 2013-2018" [National Strategy for Primary Prevention of Risk Behaviour of Children and the Youth for the Period 2013-2018]. 


\section{Theoretical Definition of the Research Questions}

In the course of their lives, humans as biological creatures become social beings. This "transformation" is composed of a series of stages accompanied by activities and driving moments, during which the characteristically human psyche and hence personality of a human develops.

"In summary, we may define that the personality formation is exposed to two classes of influence (internal and external, or biological and social) and two programs related to them - the genetic and the socializing one, which in turn are implemented through two basic mechanisms - maturing and learning." (Petrová, Plevová, 2012, p. 61).

Learning in the sense of social learning is one of the basic mechanisms of socialization. It mediates values, attitudes, norms, opinions, or social roles to the individual which are common in a given society (Paulík, 2004). As the bearer of the primary socialization of the child, the family has an undeniable significance in introducing the child into the socio-cultural environment where the child learns orientation and social symbolism (Kraus, Poláčková et al., 2001). Apart from the family, an important role in shaping and integrating the individual into society is played by school which follows up on the influence and results of the primary family socialization (Kraus, 2008). The actual stage of school education does not only serve to develop knowledge but also to shape the character, volitional and emotional traits of the child - pupil. School socialization is certainly "...the most forceful cultural factor of psychological development." (Štech In Miovský et al., 2010, p. 145).

Here, also, the conclusion holds true that if the foundations are formed weak, it will be difficult to build on them. In the field of personality formation, it is difficult to correct ingrained and fixed patterns of behaviour, which is why it is effective to minimize them through primary prevention. Hence the obvious answer to the question: "Why pay such close attention to the occurrence of risk behaviour among children, pupils and students in schools and school facilities?" Primary education is the only stage of education obligatory to all pupils. This is why emphasis is laid on the environment created inside schools and classes. These considerations particularly take into account the individual needs, possibilities and preconditions of the pupils, the creation of favourable social and emotional climate built on motivation, cooperation and methods that promote active and effective learning and teaching. This environment should be friendly and helpful. It should give the pupils the opportunity to experience success and not to be afraid (Authors, 2006). Unfortunately, students may be exposed to a number of negative effects and influences in a school environment which are purely pragmatically understood as phenomena and effects adverse to their developments. At the present, the issues of risk behaviour are given considerable attention - there are theoretical foundations and studies on whose basis mainly preventive programs are formed that seek to improve the quality of various interventions (Skopalová, 2014). It is a lively area where we look for ways to improve the system of prevention. For "...it is much easier and more profitable (in social, economic, ethical, health, and other regards) to prevent these phenomena than to deal with their consequences." (Sýkora, 2010, p. 45). The primary focus of school as an education institutions is the education, i.e. the teaching and upbringing of the children. The secondary focus is to support and help their parents. The teaching-upbringing part of educational influence can include "... creating and strengthening moral values, improving social competences of children and youth, developing those of their skills that lead to rejection of all the forms of self-destructive behaviour, expressions of aggression and violation of the law..." (Ministry of Education, 2001, p. 3), which is 
a complex and demanding activity. If there is a pupil in the class who is an aggressor or generally a pupil showing signs of serious forms of risk behaviour, the time necessary for the work with this pupil "steals" from the time available for teaching, has a negative impact on the effectiveness of teaching, not to mention the threat to the class climate and to the personal balance of pupils and teachers (Mertin, 2011).

According to the data contained in the current National Strategy for Primary Prevention of Risk Behaviour of Children and Youth, the most abundant forms of risk behaviour occurring in the school environment are bullying and cyber-bullying, truancy, smoking and alcoholism, violence, aggression and vandalism. (MEYS, 2013a). The teaching staff have a variety of tools techniques and methods at their disposal which can be used for the effectuation of primary prevention. However, the current state within the scope of the prevention of risk behaviour differs considerably in individual types of schools. The difference is present even across regions, cities and municipalities, which is determined by different degrees of orientation in the matter among pedagogues (MEYS, 2013).

The issues of risk behaviour is still current and it will continue to be so in the future. This is understandable (not only) from the current document of the MEYS dealing with this issue, since the period of school education is "... very important in shaping the personality of young people and everything that is not managed well in this period, will be very difficult to correct in time of maturity." (MEYS, 2013a, p. 3). The quoted document, presents one of already several feats of the ${ }^{1}$ Ministry of Education, Youth and Sports of the Czech Republic which builds on previous strategies and concepts relating to the prevention of substance abuse and other socially pathological phenomena among children and the youth, which began to emerge in the late 1980s. (MEYS, 2001).

In the framework of preventive effects, the period before 1989 was associated with activities of uncoordinated and unique character. Until then, there were no specific policy documents relating to the prevention of risk behaviour to speak of. The effort was rather to intimidate and discourage users of addictive substances, pointing out the risks that are associated with their use. The individuals to whom such information was disclosed, were passive listeners and lacked the opportunity for their own active involvement in preventive activities. In the early 1990s, however, a change occurred, when the steps towards the transfer of responsibility for drug-related conduct to the pupils were taken in the context of primary prevention. Over time, the orientation of primary prevention steered towards development of critical thinking, personal and social skills (Adámková In Miovský et al., 2012). The history of the concept of primary prevention is well described in the publication of prof. Miovský - Primární prevence rizikového chování ve školství [Primary Prevention of Risk Behaviour in Education] from 2010. However, the interest in these issues was not shown only by the high authorities of public administration and other bodies which are involved in the governing procedures in the area of education. In his article on the state of Czech pedagogical, Prücha talks about a specific profiling of institutes, professional workplaces and teams of scientists of the

\footnotetext{
${ }^{1}$ The current strategy for the period 2013-2018 is the fifth of similar feats (1998-2000, 2001-2004, 2005-2008, 20092012). The document always has the same structure. The issues at hand, the concepts and the agents of prevention are defined, concepts and tasks of the past years are evaluated, and new tasks for the next period are assigned. The defined goals are further specified in the individual action plans.
} 
faculties who systematically focused on specific areas of interest from which they do not divert over time but, to the contrary, they carry out further research and develop knowledge of the issues, "...becoming solid centres of pedagogical theory research... and in some workplaces, gradually creating a specific profile with long-term and systematic focus on a certain topic or discipline of pedagogy, connected also to the education of young researchers - i.e. the creation of what is called a scientific school." (Průcha, 2005, p. 238). These institutions, which represent the professional public, cooperate with with the Ministry of Education, Youth and Sports of the Czech Republic on the formation of conceptual material (MEYS, 2010). In the Czech Republic, there are several such profiled centres who follow closely the issues of risk behaviour and have the history of a range of issued publications and a number of implemented research projects on this topic. Among the most famous and most significant, it is the Department of Addictology of the First Medical Faculty of the Charles University in Prague and the General Faculty Hospital in Prague, Department of Psychology at the Philosophical Faculty of Palacký University in Olomouc.

\section{The Operationalization of Basic Concepts}

\section{School class}

Through the start of school attendance, an individual obtains the status of a pupil. This new role in life catapults the individual into the environment of a new social group where s/he is going to experience the countless personal contacts, create social relations, bonds and interactions, and will be confronted with a so far unknown authority - the teacher. All of this will be happening under the invisible but ubiquitous veil of consciousness, that the individual is part of the education system. All incoming stimuli in this group are very intense, frequent and prolonged. These qualities rank the school class, like the family, among social micro-environments of the individual (Lašek, 2001). The pedagogical dictionary understands the class as the basic social and organizational unit of school education, consisting of a group of pupils of the same age, who are taught together (Mareš, Průcha, Walterová, 2003). We may perceive this unit in different views which are not necessarily separate. The class can be seen as specifically equipped place in school (desks, chairs, blackboard), but also as a summary of the teaching objectives and contents or methods and forms of work (curriculum), including elements of group dynamics and social relations. It is in its own way always an original with specific values, rules, topics and climate. In the classroom, one can experience success and failure, cooperation and competition, support and derision.

\section{Class Climate}

In professional literature, there are a number of terms describing the socio-psychological phenomena inside the school class. The class climate is a construct which authors like to explain by saying that anyone who ever stood before a class of pupils knows exactly "what we are talking about". What are we talking about? Pupils and teachers working in a given class perceive, experience and assess the reality of the environment of the school class (in human, social and cultural terms). In addition to material conditions, there is also a subjective factor of how that 
perception, experience and assessment of participants, which represents a relatively permanent quality, exceeding a mere evaluation of teaching. Pupils and teachers initially experience individual episodes from the class environment individually. Over time, however, they enter through the interactions and common experiences a new level of values. The class is starting to be understood as "own" and a definition of the class in view of other classes occurs. Typical differences between other classes begin to shape and a collective experience is formed which lasts and may initiate a sense of the history of the class and of a specific climate. In the background of this development, we can notice the group dynamics of the class, its social relationships, communication, style of the work led by teachers, the requirements on discipline inside the class, the supervision and evaluation of the pupils, etc. The pupils in the class group foster their social skills in behaviour among their peers, experience success and disappointment, support and derision. They are also led and and taught to lead, they get into escalated situations and handle simple or more serious conflicts. If the relationships and processes within the class are perceived positively by the participants, we can speak of a functioning community which is certainly an important factor for the effective teaching process, the conditions for learning and the teacher's appetite for working with the class. There is no doubt that specific class (or school) climate has an influence on the pupils, teachers, their mood, behaviour and performance. The behaviour of the participants, even risk behaviour, is a factor and at the same time the result of a particular climate. The negative climate may ultimately signify to one of the many risk factors which has a similar weight as for example. belonging to a national minority, the low social status of the family, the environment in which the individual lives (socially excluded areas), etc. Although the individual is part of this class and of the collective influence, to some extent, s/he has the opportunity to break free from it. The amount of time a pupil spends in the class group can range from four to nine years - the first and second stage primary school, four-year and eight-year grammar school. (European Encyclopedia on National Education Systems - online). For this reason, possibilities need to be sought to equip the individuals (pupils, students, the youth) with skills that would make their encounter with the negative influences easier. Referring to experts, Skácelová states "... that up to a third of truancy is linked directly to the climate in the school, with the way the educators deal with the pupils and with unprofessional functioning of the teachers...". (Skácelová In Miovský et al., 2010, p. 185).

The very definition of the concept of class climate can be tricky, especially because it is a confrontation of objective reality with a subjective perception and experience of the participants (Grecmanová, 2008). According to the Čapek (2010, p. 13), it is "... a summary of the subjective evaluation and selfevaluation of the perceptions, experiences, emotions and the mutual influence of all participants that summon educational and other activities from them as both the co-creators and consumers in the given environment." The pupil is, however, not the only one who is being shaped by the class and school environment. Other participants such as teachers, school management, parents, etc., all reflect, experience and assess the school environment in some ways. This is a complex and longterm quality, to be set apart from the atmosphere of the school class or the school alone, which is a short-term and rapidly changing quality. We can also talk about the climate of teaching, the climate among the teachers as part of the pedagogical staff, etc. (Skopalová, 2014). Relationships inside the class, whether between the pupils and the teachers or among the pupils, are undoubtedly important for the prevention of risk behaviour inside the class groups. 


\section{Older School-Age}

Older school-age is the period defined by the entrance of pupils and students in the second stage of primary school or the first year of extended secondary school until the end of the compulsory school attendance. Among various authors, there are several views on the delimitation of the period whose start ranges from approximately around 10 and 11 year of age. E.g. Broža (Broža In Kalina et al., 2008, p. 253) talks about the period of maturing in general "...which creates the most models of behaviour that an individual uses in different variations for the rest of his or her life." Binarová defines the periods of pre-puberty, puberty and adolescence (Binarová In Šimíčková-Čížková et al., 2008). The authors mentioned define this period in unison as the transition between childhood and adulthood, which is full of changes for the individuals, both physical and mental, with different developmental speed with girls and boys. ${ }^{2}$ Individuals are subject to the demands and requirements of the "adult society", and these pressures are causing the volatility and conflicts in their own internal experience and towards their environment, in their changing ways of thinking, and in the search for their specific lifestyle and own identity. In the school environment, a criticality occurs to the requirements and school standards typical of the period, negativity and the behaviour contrary to what is expected in a given situation, sometimes in an effort to provoke. The general trend for the period of adolescence is an earlier start and later end. Broža mentions the individual's dissatisfaction as a significant sign of maturing, accompanied by feelings of anxiety and loss of security, when the individual understands that $\mathrm{s} / \mathrm{he}$ is not a child any more but at the same time is not an adult yet. This vague and insufficient state of the individual's understanding of oneself can be reflected in the behaviour of the individual, "... which can according to WHO (1969) have three basic forms: 1. Aggressive - delinquency, violence, in extreme cases terror; 2. Passive - escape from school, from the society, in extreme cases suicide; 3. Compromising - instability, addictive substance abuse." (Broža In Kalina et al., 2008, p. 257).

\section{The Risk and Problematic Pupil}

According to the Educational dictionary (Mareš, Průcha, Walterová, 2003, p. 201), risk pupils are those who have: "...bad results with a negative relationship to the school, inadequate family background, etc., for who there is an increased likelihood that they will not complete school or gain sufficient education to be able to find application on the labour market in their future life." This is often confused with the term "a problematic pupil". At the same time, the use of the term "problematic pupil" is inaccurate to some extent and often is subject to subjective designation and the teachers' feelings. Almost in every class, there are pupils who can be described as problematic. Their behaviour takes on a variety of forms. Some of the manifestations are less serious, other are dangerous. Problematic pupils designate for example those who disturb or refuse to work at all, "...lie, steal, bully their classmates, truant, roam with their group, indulge in alcohol, drugs

\footnotetext{
${ }^{2}$ Skácelová (2003) talks about second stage primary pupils as about a special group appropriate for preventive influence, as young people at this age are exposed to risk influence. It is therefore necessary to provide them with education, counselling and intervention services in the area of primary prevention of the manifestations of risk behaviour and to reduce the potential occurrence of possible problems.
} 
and sexual promiscuity." (Mareš, Průcha, Walterová, 2003, p. 179). As Kovářová and Zezulková (2013) point out, the concept of the "problematic pupil" refers to the already developed negative behaviour, whereas the term "risk pupil" is understood on the level of preventive action when the negative behaviour has not been fully developed but such a pupil is endangered by certain negative phenomena for existing reasons to a higher extent than the rest of the population and thus belongs to the risk group.

\section{Manifestations of Risk Behaviour}

The term "risk behaviour", which replaced the the term "socio-pathological phenomenon" used until 2010, is defined by Miovský as such behaviour, "in the consequence of which there is a demonstrable increase in the health, social, educational and other risks for individuals or the society." (Miovský et al., 2010, p. 23). Širúčková adds that the forms of behaviour that can be subsumed under the category of "risk" are spread along the scale between the extreme form of "normal" behaviour, i.e. extreme sports or experimentation with alcohol, up to the border of pathology, i.e. suicide attempts (Širůčková In Miovský et al., 2012). These diverse forms of conduct may not be strictly defined. What they have in common is their pre-pathological level (Širůčková In Miovský et al., 2010). For this reason, there has been a shift in terminology. The term "socio-pathological phenomenon" is a sociological concept, which refers to the fundamental and damaging phenomena in the society (alcoholism), or often to acts which are defined as criminal offences (theft, assault, murder, etc.). In the school environment, educators and other professionals encounter behaviour which is common in our society, however, which calls for the necessity of taking preventive measures, minimizing the risks of such behaviour (Prevention - info, Prevention of Risk Behaviour - online). If the diagnosis of such behaviour occurs, effective measures are introduced for their elimination (MEYS, 2010). Also, another reason is the unification of terminology in the context of the EU member countries (Skopalová, 2014).

The National Strategy of Primary Prevention of Risk Behaviour of Children and the Youth for the Period 2013-2018, which is within the competence of the MEYS targets mainly these manifestations of risk behaviour in the conduct of children and the youth (MEYS, 2013a, p. 9):

- "Interpersonal aggression - aggression, bullying, cyberbullying, and other risk forms of communication through multimedia, violence, intolerance, anti-Semitism, extremism, racism and xenophobia, homophobia;

- Delinquent behaviour in relation to material goods - vandalism, theft, graffiti and other criminal offences and misdemeanours;

- Truancy and non-fulfilment of school duties;

- Addictive behaviour - the abuse of addictive substances, internet addiction, gambling;

- Risk sports activities, injury prevention;

- Risk behaviour in traffic, accident prevention;

- The spectrum of eating disorders;

- The negative influence of sects;

- Hazardous sexual behaviour".

Since 1998 the definition of specific phenomena has passed on which preventive activities are directed by several regulations. It is understandable. Over time, new threats arise and will arise which 
must be responded to. In older documents, we encounter the traditional risk manifestations, such as truancy, smoking and alcoholism of the youth. Nowadays, with the development of possibilities in all directions, we are facing the phenomena which are associated with risks previously absent. The current definition takes into account the developments in computer technology and the Internet, new sports activities, but also the naming of new ways of addictive behaviour, previously unknown or not perceived as endangering.

\section{Primary Prevention of the Manifestations of Risk Behaviour}

In general, the primary prevention is understood as the creation and use of measures which aim to prevent negative phenomena. In school prevention, we distinguish primary, secondary and tertiary prevention according to the escalation level of the undesirable phenomenon and the time for preventive intervention. Thanks to the various natures of measures and tools, there are a number of options of how to divide the concept of "primary prevention" or its meaning and content. One of the options is to divide primary prevention into non-specific and specific. In the classroom environment, primary prevention is aimed at preventing problems and consequences of harmful social development. It is a comprehensive effort to eliminate or minimize these symptoms and to create quality interpersonal relationships within the class. There is an effort on the positive class climate (Skopalová, 2014). According to Čech (Čech In Miovský et al., 2012, p. 109), primary prevention should be understood as a means of immunization, protection of individuals or groups from the negative effects, not through isolation from these influences - that is not quite possible but through "...educational, preventive and intervening work that will be involved in an individual's (especially a child's or an adolescent's) shaping of the right attitudes and the necessary knowledge and skills that make him/her able to live in a society where risk behaviour and phenomena do occur, able to recognize them and not let them endanger him/her."

However, school activities in primary prevention reach beyond the boundaries of the class or school environment. Its goal is to provide intervention in cases of "...traumatic experiences - domestic violence, bullying, violent behaviour, abuse of and cruelty to children, including commercial sexual abuse, endangering the child's upbringing, experimenting with drugs (legal and illicit substances), risk eating habits leading to eating disorders (bulimia nervosa, anorexia nervosa)." (MEYS, 2010, pp. 1-2).

Non-specific primary prevention affects individuals or groups in general, not specifically. It presents activities that "...form an integral part of primary prevention and contain all methods and approaches enabling the development of a harmonious personality, including the possibility of developing talents, interests and physical and sports activities." (MEYS, 2005, p. 9). It aims at the support of desirable forms of behaviour, implementing educational approaches positively shaping the personality, attitudes, values and the development of interests. These are often leisure-time activities which help finding enriching ways to spend leisure time, teaching children and adolescents to use and dispose of it in a rational manner. The place of implementation of non-specific primary prevention is mainly the family and school (Čech In Miovský et al., 2012).

The means of specific primary prevention selectively target specific risks. It forms a "...system of activities and services that focus on working with the population who in their absence can be 
expected to further develop in a negative direction, and that seeks to prevent or limit the growth of the occurrence of such development." (MEYS, 2005, p. 9). Specific primary prevention complements and builds on the non-specific primary prevention. It focuses on preventing and minimizing the occurrence of risks, as such. bullying, aggression, truancy and so on. It adopts a holistic approach to addressing these unwanted phenomena. The principal point of its implementation is the school as an educational institution (Čech In Miovský, 2012). According to the focus on the target group, resources and tools, we may divide specific primary prevention into three levels.

Universal primary prevention is aimed at the population of children and the youth in general. It implements programs for a larger number of people (classes) taking into account their age and if appropriate, other significant social factors. The sufficient qualification for its practical implementation of prevention on this level is a completed education of a school prevention methodologist according to the law and the Decree no. 317/2005 on Further Education of Pedagogical Staff, ideally with secured intervision and supervision (Černý In Milovský et al., 2010, pp. 42-43).

Selective primary prevention is focused on individuals and groups in greater extent of exposure to risk factors. These individuals and groups are more at risk. It is implemented with a small number of people or with individuals separately. This level includes sociopsychological programs for selected groups of people which consist of learning e.g. social skills, communication skills and the development of interpersonal relationships. The persons implementing these programs are already working with a group of people at a higher risk and their education should be appropriate, i.e. in special education, psychology, addictology, etc. (Černý In Miovský et al., 2010, pp. 42-43).

Indicated primary prevention is focused on the individual. It consists of individual work with a client who has been exposed to risk factors or manifested forms of risk behaviour. At this level, the task at hand is a specific intervention, therefore it is necessary to make a number of steps related to the assessment of the nature and specificity of the case (bullying, truancy, substance abuse, etc.). The aim is to recognize the problem as soon as possible, choose a suitable solution procedure and initiate the intervention immediately. To implement the indicated primary prevention, it is necessary to have proper education, e.g. in the field of special education, psychology, addictology, etc. (Černý In Miovský et al., 2010, pp. 42-43).

\section{Performance of Primary Prevention}

Until 2004, the system of primary prevention was defined by methodical guidelines of the MEYS. Until the force of Act no. 561/2004 Coll., on Preschool, Basic, Secondary, Tertiary Professional and Other Education (the Education Act), it was the Methodical Instruction of the MEYS for the Prevention of Socio-Pathological Phenomena ref. No. 14515 from 2001. The Government Decree no. 549/2003, on the Enhancement of the National Drug Policy put the MEYS in charge of the coordinating activities in the field of primary drug prevention at the inter-ministerial level (MEYS, 2005) and after the effective date of the Education Act, the school became the fundamental pillars in the primary prevention of risk behaviour. The preventive function is mentioned in Section 29 where schools and school facilities are"...obliged to take into account fundamental physiological 
needs of children, pupils, and students and to create conditions for their healthy development and for preventing the rise of pathological social phenomena." (Section 29 of Act no. 561/2004 Coll., 2004). The law declares the right of pupils, students and their legal representatives to counselling aid from the school or school counselling facility in matters of education. However, pupils and students have an obligation to respect internal rules, regulations and guidelines of the school or school facility for the protection of health and safety. Legal representatives shall ensure that children and pupils attend the school and school facility and personally participate in the discussion on major issues related to the education of their children. Conditions ensuring health and safety and the protection from socio-pathological phenomena or e.g. manifestations of discrimination, hostility or violence among children, pupils and students are regulated by the School Rules of Order and Internal Rules of Order (Section 21, Section 22, and Section 30 of the Act no. 561/2004 Coll., 2004).

Decree no. 72/2005, on the Provision of Counselling Services in Schools and School Counselling Facilities determines the activities of the prevention methodologist in a Pedagogical-Psychological Counselling Facility (henceforth "PPCF") and of the school prevention methodologist. It stipulates that the counselling facility "through the prevention methodologist, ensures prevention of sociopathological phenomena, the implementation of preventive measures and coordination of school prevention methodologists." (Section 5, Subsection 3e of the Decree no. 72/2005 Coll., 2005). The legislative document specifies the methodologist's scope of activities in "Annex II - Standard Activities of School Prevention Methodologist". Despite this, the activity of the methodologist is delimited in relatively general terms and activities to be performed by workers in this position are only discussed in more detail in the Methodological Recommendation for Primary Prevention of Risk Behaviour in Children, Pupils and Students in Schools and Educational Establishments no. $21291 / 2010-28$. In this text, the work of the methodologist is described in general terms whose interpretation can be diverse. This issue is also reflected by the current National Strategy for Primary Prevention which states as one of the primary objectives "adequate definition of the activities of the methodologist of prevention in a Pedagogical-Psychological Counselling Facility" (MEYS, 2013a).

Methodological Recommendation for Primary Prevention of Risk Behaviour in Children, Pupils and Students in Schools and Educational Establishments no. 21291/2010-28 is another of the core documents of the MEYS in the field of prevention of risk behaviour in schools and educational establishments. The authors of the document transmit a recommendation of procedure for the selection of partners for the implementation of the Minimum Prevention Program and also deal with the financial remuneration of school prevention methodologists and prevention methodologists of a PPCF. Twenty annexes to this document have been created which constitute the framework blueprints and describe the pedagogical procedures upon the presence of certain types of risk behaviour in the school environment, corresponding with the types of risk behaviour. The authors of individual texts make freely available to interested parties good "first aid" in the form of methodological instructions including a description of the type of risk behaviour, their foundations and risk factors; contacts to cooperation partners; the legislation, descriptions of the types of prevention for the specific risk behaviour; recommended and inappropriate procedures; who to notify in which cases, and links to professional literature for specific types of manifestations of risk behaviour (MEYS, 2013a). 


\section{Selected Educational Tools for the Prevention of Risk Behaviour}

\section{The School Rules of Order}

An important starting point for the prevention of risk behaviour in the school environment is a set of well designed internal rules. The School Rules of Order constitute a fundamental, key document which stems from Section 30 of the Education Act, as the Principal of the school issued the School Rules of Order and the Director of the Schooling Facility issues the Internal Rules of Order. These rules govern the details of the rights and obligations of the pupils and their legal representatives, including the rules of mutual relationships with the educational staff. It described the conditions for ensuring the health and safety of the pupils from socially pathological phenomena and conditions of treatment of the school property (Section 30 of the Act no. 561/2004 Coll., 2004). Other documents are founded on the text of the Rules of Order - the Internal Directives, the Crisis Plan and the Security Plan. The text of the Rules of Order is founded on the specific nature of the school (type and focus, the composition of the pupils, the district area of the school, etc.). The document can be optionally amended by other internal standards. The significance of the School Rules of Order is underlined for example by the fact that it is the subject of the examination of every inspection carried out by the Czech School Inspectorate.

\section{The School Preventive Program/Strategy}

The obligation of schools and educational institutions to create school prevention strategies (also called program, henceforth as "SPP") was first defined in the Methodological Instruction of the MEYS $20006 / 2007-51$ in 2007. The SPP is a long-term program (most commonly a 5-year one) which defines the long-term, medium-term and short-term goals for students, teachers and sometimes the parents. The SPP is part of the School Curriculum Program, which is based on the Core Curriculum Program. This guideline defined topics which schools and school facilities should follow in the prevention of risk phenomena and behaviour of the pupils, including their recognition and the provision for an intervention. In 2010, there have been changes to the orientation and the original document with the defined range of topics was revised by the Methodological Recommendations no. 21291/201028. Each school and school facility is different, they are seated in different environments and have different staff composition and pupil composition, all of whom live and come from various conditions. As the types of risk behaviour in different schools do not have the same frequency and intensity of development, preparing their SPP, schools and educational institutions have to deal with the question of what topics or which types of the manifestations of risk behaviour they need to pay attention to in the form of specific, selective and indicated prevention. School prevention strategy takes into account the specific population of the school and school surroundings, respecting the school environment. The effort is to keep the effect the program for over the longest possible period of time. (MEYS, 2010).

\section{Minimum Prevention Program}

Minimum Preventive Programme (henceforth MPP) is a systemic element of preventive activities of school educational facilities, whose elaboration and implementation is mandatory as of January 2001 (MEYS, 2001). An MPP has the form of a document that is prepared for one school year and 
supervised by the Czech School Inspectorate. The document is compiled by the school prevention methodologist, but (ideally already) its elaboration and effectuation is carried out by the participation of the whole pedagogical staff. Its implementation is subject to continuous assessment and at the end of the school year, the effectiveness of primary prevention strategies contained therein is evaluated. This assessment is also reflected in the annual report on the activities of the school (MEYS, 2010). Miovský, Skácelová and Čablová (Miovský et al., 2012) claim that the MPP should consist of at least three components:

1. A set of rules to improve the safety of children at school and at school events-school operation rules which go beyond the legally defined responsibilities. It may take on the form of recommendation related to school activities and events.

2. Programs aimed at developing skills for life, consisting of programs aimed at developing social skills and skills of self-influence - programs developing the capacity to face social pressure, to cope with the stressful situations of conflict, to master the art of assertive behaviour, empathy, and communication. Also learning strategies regarding the work with one's own behaviour and its positive and wanted change or learning stress management techniques.

3. Programs specifically targeting various forms of risk behaviour - the use of specific programs and interventions. The MPP should incorporate partial procedures for dealing with all the basic types of risk behaviour with regard to age groups or classes.

The MPP is essentially a work-flow and organizational plan all in one that should by its scope affect the teaching and education of pupils in the areas of healthy lifestyles, communication skills, personality and social-emotional development. The familiarization of the pupils with these issues happens in the context of all or specific school subjects, on road trips, tours, talks and seminars, and others.

\section{Individual Education Program (IEP)}

Since 2014, schools have an instrument strengthening the responsibility of parents for a child's education, the so-called. "Individual Education Program" (henceforth "IEP"). It is "one of the stages of structured conduct in solving risk behaviour of a pupil in the school context." (National Institute of Education, 2013, p. 4). The program serves as a tool for prevention, cooperation with the legal representatives of the pupils, cooperation with the relevant institutions, and above all as a solution to risk behaviour of pupils. It does not have the character of punishment. Its concept builds on the fact that the solution involves all stakeholders, i.e. the pupil, his representatives and schools. It does not try to delegate the responsibility of only one entity and it tries to solve the pressing problems which are the lack of pupils' discipline and the disinterest of the parents. The tool was developed based on the increasing number of educational problems solved in schools. The advantage of the IEP is that it provides a unified approach to solving problems, "...while to a certain extent it prevents possible escalation of the problems when left unchecked, or in case of wrong procedure of solving educational problems." (Kupčík, Skopalová, 2014, p. 2).

The protocol itself is as follows: After identifying the problems, the parents are contacted with whom cooperation is established relating to the problematic phenomenon. If the problem persists, the focus increases, the cooperation with legal representatives intensifies and other institutions may get involved. A support plan is created which specifies the duties and obligations of the parties 
involved (Mertin, 2011). The cooperation among the various agents in the form of discussions and meetings are recorded in forms.

\section{Empirical Part}

As part of the research titled "Class Climates at the Second Stage of Primary Schools in View of Risk Behaviour in the Class", the research team focused on the issues of class climate in connection with the occurrence of risk behaviour. The research was conducted as part of the project IGA_PdF_20140213. The mentioned project continues in the form of a research survey which was carried out with the support of the Pedagogical Faculty of Palacký University in Olomouc IGA_PdF_2015019². The intention was to answer the question, whether and how the incidence of risk behaviour affects class climates in schools that participated in the research. Through the project, the participants in the research team were able to contribute with their activity to finding imaginary lines and connections related to the psychosocial phenomenon in the class group while working with pupils of older school age and with their classroom teachers. The following research questions were formulated: How does the occurrence of risk behaviour influences the climate of the class and what is the role of the class teacher in preventing risk behaviour? The research sample consisted of 756 respondents aged 12-16 years - second stage primary school pupils, and 35 class teachers. ${ }^{5}$ The survey was conducted in five primary schools in the Olomouc Region of various focus, character and specialization. Therefore, it was an ex-post-facto field survey study. Addressing schools and negotiating co-operative agreements in the framework of the research, we committed ourselves that none of the schools in which the investigation is done will be named in the final report (schools are marked A, B, C, D and E).

Table no. 1 The research sample for Milestone 1

\begin{tabular}{|c|c|c|l|}
\hline school & total no. & relative no. & closer primary school information \\
\hline Primary A & 120 & $15.87 \%$ & village (3 thousand inhabitants) 15 km from Olomouc \\
\hline Primary B & 213 & $28.17 \%$ & specialized school in district Olomouc \\
\hline Primary C & 181 & $23.94 \%$ & town (12 thousand inhabitants) 30 km from Olomouc \\
\hline Primary D & 86 & $11.38 \%$ & village (2.5 thousand inhabitants) 130 km from Olomouc \\
\hline Primary E & 156 & $20.63 \%$ & housing project school in district Olomouc \\
\hline
\end{tabular}

\footnotetext{
${ }^{3}$ Grecmanová, H., Skopalová, J., Blaštíková, L., Zelinka J. Klima tř́dy na 2. stupni základních škol z hlediska projevů rizikového chováni ve trídè. [Class Climates at the Second Stage of Primary Schools in View of Risk Behaviour in the Class]. Project implemented at the Pedagogical Faculty of Palacký University in Olomouc, 2014.

${ }^{4}$ Grecmanová, H., Skopalová, J., Blaštíková, L., Nováková, Z., Pitnerová, D., Raszková, T., Peřinová, K. Klima školy a jeho ovlivnění školním metodikem prevence a sociálním pedagogem na základní škole. [School Climate and The Influence of the School Prevention Methodologist and Social Pedagogue at Primary School]. Project implemented at the Pedagogical Faculty of Palacký University in Olomouc, 2015.

${ }^{5}$ Although the implementation of the prevention of risk behaviour and its subsequent solution of the behaviour at the schools also in practice involves school psychologists, they were not included in the survey as not every school has its own school psychologist.
} 
Based on the testimonies of students and class teachers the climate of classes was described where risk behaviour was identified. In the framework of the investigation, the working hypothesis was: "In the case of the occurrence of risk behaviour in the class, we find adverse class climate."

The objective of the research survey:

1. to describe the climate in the classes where risk behaviour has been identified from the perspective of pupils and class teachers; to describe climate in classes where risk behaviour has not yet been identified from the perspective of students and class teachers;

2. to identify the differences in the perceptions of the climate among the respondents - in particular, to compare the views of class teachers and pupils on the class climate at primary school;

3. to inform the schools who took part in the research on the results of the class climate and manifestations of risk behaviour.

The research team dealt with the questions:

- Does the incidence of risk behaviour affects the climate of the class?

- If so, in what ways?

For this research project, mixed research was chosen - quantitative approach with the use of statistical processing of the data (questionnaire for pupils and class teacher) and semi-structured interviews with school prevention methodologists. ${ }^{6}$

Since the turn of May and June $2014^{7}$, the questionnaire survey was carried out at selected schools of the Olomouc Region. Attention was also paid to the cooperation of the subjects with other institutions and partners in prevention. The goal is to detect the presence of specific manifestations of risk behaviour, to determination and compare the tools which the selected schools use for the prevention of the occurrence of manifestations of risk behaviour of the pupils, and for their solution. The team subsequently dealt with the views of the prevention methodologists on the circumstances related to the performance of this position. The commitments determined were divided into three milestones:

Milestone no. 1 - "Determining the occurrence of specific manifestations of risk behaviour in primary schools which are involved in the research in the framework of the IGA_PdF_2014021 project."

Milestone no. 2 - "Determining tools that the selected schools use in preventing the occurrence of and in solving the manifestations of risk behaviour of the pupils. Cooperation of the primary schools with other entities in prevention. The opinions of prevention methodologists on the circumstances related to the performance of their position."

Milestone no. 3 - "Comparison of the tools that the selected schools use in preventing the occurrence of and in solving the manifestations of risk behaviour of the pupils. A reflection on the opinions of the prevention methodologists on the circumstances connected with the performance of their position."

\footnotetext{
${ }^{6}$ The research implemented within as part of the project IGA was an example of research that set the problems and phenomena to the relational and causal plane. The researchers dealt with the relation between class climate and risk behaviour, working with several variables - class climate, the incidence of risk behaviour, the assessment of the class climate by the teacher, type of school.

${ }^{7}$ The intention was to capture a time when the interviewed pupils and teachers were not yet affected by the thoughts of the summer break, but when the questionnaire survey would not disturb the activities related to the end of the school year.
} 
The paper, then, can be understood as a kind of evaluation of the existing efforts of schools which, however, rather has the inspirational rather than revising ambitions. In the context of fulfilling the set goals, we were able to answer the following questions:

- "What types and forms of risk behaviour occur in the selected schools?"

- "What phenomena do the pupils consider as annoying in the context of the class group?"

- "What tools the schools use for the prevention and solution of the occurrence of risk behaviour?"

- "Do the selected schools cooperate with other institutions on the implementation of primary prevention?"

- "What is the selected school prevention methodologists' opinion on the elaboration of the Minimum Prevention Program?"

Milestone no. 1 - "Determining the occurrence of specific manifestations of risk behaviour in primary schools which are involved in the research in the framework of the IGA_PdF_2014021 project."

These initial data which served as a springboard, were obtained through the questionnaire on the perception of class climate change class for the pupils of selected primary schools. It was composed of thirty-two items. There were twenty-six polytomic items where the pupils selected from predefined answers ("yes; sometimes yes, sometimes not; not"). Also, in three of the items, the pupils were offered to add an explanation of the phenomenon (e.g. "There are conflicts among the classmates, what are they about?"). Our intention was to split the classes based on the identification of the presence of risk behaviour in the most general level (has/has not been identified) and further analyze them in terms of gravity.

The range of research questions which the listed answers were gained for using the data collection techniques are the following:

- "What types and forms of risk behaviour occur in the selected schools?"

- "What phenomena do the pupils consider as annoying in the context of the class group?"

The pupils were given the opportunity to describe the situations that annoy, insult or otherwise affect them. At the same time, they were given space to reflect on them and express those that were not comprised by the questionnaire. Thanks to the ability to list the specific phenomena and, de facto, raise complaints about the problems in their class group, we obtained an amount of information which helped us get an idea of the relations in each class community.

Manifestations of risk behaviour may take various forms. The questionnaire survey revealed that in all the investigated classes, the occurring manifestations of risk behaviour were of different nature. The more severe forms take on the guise of physical assaults and psychological coercion. The respondents in the school environment with aggressive and violent behaviour of classmates witnessed the instigation and progress of fights, brawls and conflicts of various origin. Attacks among classmates, the "daring" of the stronger to maltreat the weaker and treating others as a "puppet or servant" are not sporadic phenomena in the class communities. We may talk about the initial stages of bullying which was also included in the testimony of the pupils. Non-physical attacks do not hurt the body, however, they all the worse affect the internal integrity of the pupils. For that reason, manifestations of such behaviour as defamation and making reciprocal spiteful actions, contempt, pushing aside and threats, no less serious. The embarrassing and ridiculing of classmates and the resulting mockery, for example because of the colour of skin, nationality, sexual orientation, including racist comments, insults to the 
pupils themselves and to their families, swearwords and verbal attacks, are phenomena which degrade and humiliate the persons of the affected pupils, which may lead to their separation from the class. A common phenomenon is the vulgar language, smoking and breaking and stealing things. A higher accumulation of these serious phenomena was recorded in some classes. On the other hand, there are well functioning class groups where there are variants of risk phenomena denotable as milder - throwing things, sports games during breaks, nagging, provocations, running around the classroom, the noise and clamour during the breaks. Still, it is risk behaviour which carries certain dangers with it.

Milestone no. 2 - "Determining tools that the selected schools use in preventing the occurrence of and solution to the manifestations of risk behaviour of the pupils. Cooperation of the primary schools with other entities in prevention. The opinions of prevention methodologists on the circumstances related to the performance of their position."

Based on the determined result of the occurrence of risk behaviour in the schools examined, we have selected three of the primary school which we focused on in further research. They are Primary A, Primary B and Primary C. The range of research questions we obtained the answers to using the techniques mentioned is as follows:

- "What tools the school used for the prevention and solution of the occurrence of risk behaviour?"

- "Do the selected schools cooperate with other institutions on the implementation of primary prevention?"

- "What is the selected school prevention methodologists' opinion on the elaboration of the Minimum Prevention Program?"

To determine the tools and methods that individual schools use in connection with the prevention of and the solution to the risk behaviour, we used a technique of the analysis of documents that all the schools have elaborated. They are School Rules of Order and Minimum Prevention Programs. To specify other relevant information, we used the technique of interview, which we conducted with school prevention methodologists in the primary schools listed above.

Table no. 2 The research sample for Milestone 2

\begin{tabular}{|l|l|l|l|}
\hline \multirow{2}{*}{ School } & $\begin{array}{l}\text { Research } \\
\text { Technique }\end{array}$ & Research Sample & Additional Information \\
\hline \multirow{2}{*}{ Primary A } & $\begin{array}{l}\text { Analysis } \\
\text { of Documents }\end{array}$ & The School Rules of Order & Valid from 9/2014 \\
\cline { 2 - 4 } & Interview & $\begin{array}{l}\text { Minimum Prevention Program } \\
\text { of Primary A }\end{array}$ & School Year 2014/2015 \\
\hline \multirow{3}{*}{ Primary B } & $\begin{array}{l}\text { Analysis } \\
\text { of Documents }\end{array}$ & The School Rules of Order & $\begin{array}{l}\text { Working in the field of prevention } \\
\text { for 8 years }\end{array}$ \\
\cline { 2 - 4 } & Interview & Minimum Prevention Program & School Year 2014/2015 \\
\hline \multirow{2}{*}{ Primary C } & $\begin{array}{l}\text { The Prevention Methodologist } \\
\text { of Primary B }\end{array}$ & $\begin{array}{l}\text { Working in the field of prevention } \\
\text { for 15 years }\end{array}$ \\
\cline { 2 - 4 } & of Documents & The School Rules of Order & Valid from 9/2013 \\
\cline { 2 - 4 } & Interview & $\begin{array}{l}\text { Minimum Prevention Program } \\
\text { of Primary C }\end{array}$ & School Year 2014/2015 \\
\hline
\end{tabular}


The reason for choosing this combination of document analysis and interview as research techniques lies in the specificity of the elaboration of these documents at each individual school. The School Rules of Order primarily affect the range of topics which are defined by the law and whose absence would mean a conflict with the legislation. Other thematic units, however, may be amended optionally. The Minimum Prevention Program rather presents a recommended structure. This specificity in its elaboration is the reason for the choice of another data collection tools.

The interview with school prevention methodologists provided answers to the questions which the analyzed documents did not address but which are actually carried out at the school.

The initial contact with the school prevention methodologists was electronic (May-June 2015), when we briefly introduced ourselves, clarified the subject of interest and the specifications of the range of topics which the interview should relate to. For the purpose of the interview, we prepared a so-called. interview guide (aid), which took the form of twenty-five questions divided into five thematic units (the performance of the function of school prevention methodologist, the Minimum Prevention Program, the procedure for solving risk behaviour, the cooperation with internal and external entities in the prevention and solution of risk behaviour, the tools and methods used for primary prevention of risk behaviour). After the methodologists' consent to give us some of their time to answer the questions, we arranged an appointment. In the course of the interview, we had a notepad to write the answers in. At the conclusion, we checked the notes with the respondents so as to avoid inaccurate or misleading information. The interviews lasted from 30 to 45 minutes. The documents were examined in view of the range of basic and specific questions. In the basic questions, we concerned ourselves with the primary information which is the origin of the document, the date of elaboration, the effect period and the content. Special questions were formulated based on criteria-compounded aspects. Defining the aspects to assemble the criteria, we took into account the fact that the documents are fundamentally different in nature (Rules of Order providing for the conditions of the school operation vs. preventive program de facto a workflow and organisation plan). For this reason, it was necessary to adjust the starting points for each of the observed documents.

The School Rules of Order and the Minimum Prevention Program are documents which are to be used to pass information to the pupils, their legal representatives, the educators and the potentially interested public. Therefore, the quality of the presentation plays a fundamental role. The pupils, the pedagogues and the legal representatives should be introduced to the wording of the documents which requires such a text edit that allows pupils of all ages to understand the requirements. The criterion specified by us is made up of two aspects we chose to examine, i.e. accessibility and clarity. The criterion is the same for both types of documents.

Under the criteria of actions and means, we were interested - regarding the School Rules of Order - in the presence of the sets of rules to increase the safety of children at school and at school events. We were also interested whether the Rules of Order comprise the issues of the role of class teachers, including teacher specialists - the rank which includes the position of school prevention methodologist. We observed the occurrence of other, optional amended documents.

In relation to our intentions, we identify how much space in the Rules of Order is devoted to prevention of risk behaviour. For this reason, we have included the criterion of "frequency of the topic of primary prevention of risk behaviour".

To obtain information about the tools that are used at the selected schools in connection with risk 
behaviour and the data on any cooperation of the examined entities other institutions and partners, we used the analysis of available documents for each facility regarding this issue. The topical range which must be defined in the Rules of Order, is prescribed by Section 30 of the Education Act. If the Rules of Order did not meet these requirements, it would be a violation of the law. All schools have included the required provisions in their Rules of Order. Despite that, we can notice the inclusion of specific provisions of each of the schools which take into account their default conditions. What these three selected schools have in common is the emphasis on prevention of specific manifestations of risk behaviour. Specifically, it is the protection of the pupils from addictive substances and bullying. In all of the Rules of Order, there was a mention of interest recreational activities provided by the school which certainly is a positive phenomenon despite recent polemics appearing in which some individual authors dispute, or conversely highlight the effect of this form of non-specific prevention. Minimum Prevention Programs are compiled "only" on the basis of recommendations. Schools have a freer hand in their elaboration. In our case, we met with two relatively generously elaborated programs and one program providing most concise (yet sufficient) information. Neither of these options is to the harm. The schools reflect their conditions, the incidence of risk behaviour in their environment, their own tools, methods and means. For this reason, the text quantity cannot be equated with its quality. This freedom in the form of elaboration is to some extent convenient and eases the conditions for compulsory yearly processing of the Minimum Prevention Program. In two cases, the schools refer to the Methodical Instructions of the Minister of Education, Youth and Sports to the Prevention of Socially Pathological Phenomena Among Children and the Youth no.: 14514/2000-51 and to the Methodological Instruction to the Primary Prevention of Socially Pathological Phenomena Among Children, Pupils and Students in Schools and Educational Facilities of the MEYS no. 20006/2007-51. The trouble is that the latter was abolished and replaced by an instruction from the year 2000 and in 2010, even this one was abolished and replaced with a Methodical recommendation No. 21291/2010-28, which we have discussed in Chapter 4 of the theoretical part. These are essentially similar documents which are identical in principle and structure. However, the terminology used is different, focusing on topical units, generally reflecting on and departing from a different state of knowledge in the area of primary prevention of risk behaviour in schools and educational establishments.

In the School Rules of Order, (primary) prevention of risk behaviour is not mentioned, but the term socio-pathological phenomenon is used (an older term used until 2010). Once again, we return to the issues of the availability of older versions of the instructions and recommendations which can be encountered without greater efforts and for which it is not clear whether they are or are not valid. Milestone no. 3 - "Comparison of the tools that the selected schools use in preventing the occurrence of and in solving the manifestations of risk behaviour of the pupils. A reflection on the opinions of the prevention methodologists on the circumstances related to the performance of their position." The results of the analysis of the documents were supplemented by findings based on the semistructured interviews with school prevention methodologists. After that, we had obtained everything for the comparison of the tools that the selected schools use in preventing the occurrence of and in solving the manifestations of risk behaviour of the pupils.

Based on the information we had gained through the analysis of documents and the series of interviews with school prevention methodologists, we have created the following table. 
Table no. 3 School Tools Preventing and Solving Manifestations of Risk Behaviour (a)

\begin{tabular}{|c|c|c|c|}
\hline \multirow[t]{2}{*}{ Range of Topics } & \multicolumn{3}{|c|}{ Selected Primary Schools } \\
\hline & Primary A & Primary B & Primary C \\
\hline $\begin{array}{l}\text { Methods Applied } \\
\text { in Prevention }\end{array}$ & $\begin{array}{l}\text { discussions; talks; } \\
\text { lectures; } \\
\text { playing sketches; } \\
\text { open learning; } \\
\text { self-evaluation; } \\
\text { interpretation method; } \\
\text { storytelling (good } \\
\text { examples and stories) }\end{array}$ & $\begin{array}{l}\text { discussions; talks; } \\
\text { lectures; } \\
\text { improvisation; } \\
\text { drama plays; } \\
\text { interactive games; } \\
\text { cooperative learning; } \\
\text { active listening; } \\
\text { training of stress } \\
\text { situations }\end{array}$ & $\begin{array}{l}\text { talks; lectures; } \\
\text { consultations; } \\
\text { playing sketches; } \\
\text { thematic games; } \\
\text { peer programs; } \\
\text { problem solving; } \\
\text { critical thinking; } \\
\text { discussions and } \\
\text { debating circles }\end{array}$ \\
\hline $\begin{array}{l}\text { Organizational } \\
\text { Forms of Teaching }\end{array}$ & $\begin{array}{l}\text { excursions; walks; } \\
\text { frontal teaching; } \\
\text { community circle; } \\
\text { vocational classrooms; } \\
\text { group-work; } \\
\text { individual work; } \\
\text { pupil competition; } \\
\text { pupils' Olympics }\end{array}$ & $\begin{array}{l}\text { excursions; walks; } \\
\text { frontal teaching; } \\
\text { community circle; } \\
\text { vocational classrooms; } \\
\text { individual work; } \\
\text { pupil competition; } \\
\text { pupil Olympics; } \\
\text { cooperation in a group }\end{array}$ & $\begin{array}{l}\text { excursions; walks; } \\
\text { frontal teaching; } \\
\text { community circle; } \\
\text { vocational classrooms; } \\
\text { individual work; } \\
\text { pupil competition; } \\
\text { pupil Olympics }\end{array}$ \\
\hline $\begin{array}{l}\text { School Subjects } \\
\text { Related to Prevention }\end{array}$ & $\begin{array}{l}\text { history; chemistry; } \\
\text { literature; } \\
\text { science; } \\
\text { Czech language; } \\
\text { health education; } \\
\text { civic education }\end{array}$ & $\begin{array}{l}\text { health education; } \\
\text { civic education; } \\
\text { all subjects where the } \\
\text { topic of prevention can } \\
\text { be incorporated }\end{array}$ & $\begin{array}{l}\text { chemistry; science; } \\
\text { mental hygiene; } \\
\text { assertive behaviour; } \\
\text { civic education; } \\
\text { health education; } \\
\text { relaxation techniques } \\
\text { against fatigue and } \\
\text { stress }\end{array}$ \\
\hline $\begin{array}{l}\text { Training in model } \\
\text { situations }\end{array}$ & yes & yes & yes \\
\hline $\begin{array}{l}\text { Feedback } \\
\text { from the pupils }\end{array}$ & $\begin{array}{l}\text { discussion; } \\
\text { self-evaluation }\end{array}$ & $\begin{array}{l}\text { discussion; } \\
\text { questionnaires; } \\
\text { community circle }\end{array}$ & community circle \\
\hline $\begin{array}{l}\text { Extracurricular } \\
\text { Activities Supported } \\
\text { by the School }\end{array}$ & $\begin{array}{l}\text { trips; } \\
\text { interest clubs; } \\
\text { sports activities; } \\
\text { leisure-time activities }\end{array}$ & $\begin{array}{l}\text { interest clubs; } \\
\text { sports activities; } \\
\text { physical activities }\end{array}$ & $\begin{array}{l}\text { interest clubs; } \\
\text { sports activities }\end{array}$ \\
\hline $\begin{array}{l}\text { Other Forms } \\
\text { of School Activities }\end{array}$ & $\begin{array}{l}\text { concerts; } \\
\text { school trips; } \\
\text { ski courses; } \\
\text { school in nature }\end{array}$ & $\begin{array}{l}\text { tours; concerts; } \\
\text { school trips; } \\
\text { experiential lessons; } \\
\text { gallery animation; } \\
\text { team-building stays }\end{array}$ & $\begin{array}{l}\text { class events; } \\
\text { school trips; } \\
\text { entertainment events; } \\
\text { ski courses; } \\
\text { experiential lessons }\end{array}$ \\
\hline
\end{tabular}


Table no. 4 School Tools Preventing and Solving Manifestations of Risk Behaviour (b)

\begin{tabular}{|c|c|c|c|}
\hline \multirow[t]{2}{*}{ Range of Topics } & \multicolumn{3}{|c|}{ Selected Primary Schools } \\
\hline & Primary A & Primary B & Primary C \\
\hline $\begin{array}{l}\text { Methodological } \\
\text { Meeting } \\
\text { of Pedagogues } \\
\text { on Prevention }\end{array}$ & $\begin{array}{l}\text { in the context } \\
\text { of the regular } \\
\text { pedagogical staff } \\
\text { meetings }\end{array}$ & $\begin{array}{l}\text { seminars with experts } \\
\text { for pedagogues }\end{array}$ & $\begin{array}{l}\text { in the context } \\
\text { of pedagogical councils } \\
\text { (twice a year); } \\
\text { meetings of the } \\
\text { pedagogical staff }\end{array}$ \\
\hline $\begin{array}{l}\text { Crisis Scenario for } \\
\text { the Solution of Risk } \\
\text { Behaviour }\end{array}$ & no & yes & yes \\
\hline Use of IEP & no & no & no \\
\hline $\begin{array}{l}\text { Class-Managing } \\
\text { Lessons }\end{array}$ & yes, when needed & yes, when needed & yes, when needed \\
\hline $\begin{array}{l}\text { Cooperating Institu- } \\
\text { tions and Experts on } \\
\text { Prevention }\end{array}$ & $\begin{array}{l}\text { Police of the } \\
\text { Czech Republic; } \\
\text { ACET Czech Republic } \\
\text { PBC [ACET ČR o.p.s.]; } \\
\text { P-Center Association } \\
\text { [P-centrum, spolek]; } \\
\text { People in Need, PBC } \\
\text { [Člověk v tísni, o.p.s.]; } \\
\text { specialists across } \\
\text { disciplines (curators, } \\
\text { doctors) }\end{array}$ & $\begin{array}{l}\text { Police of } \\
\text { the Czech Republic; } \\
\text { PPCF Olomouc } \\
\text { ARPOK PBC; } \\
\text { SPC Pramínek PBC; } \\
\text { Municipal police; } \\
\text { Association D PBC } \\
\text { [Sdružení D o.p.s.]; } \\
\text { E-Safety Counselling; } \\
\text { P-Center Association } \\
\text { [P-centrum, spolek]; } \\
\text { The Department of } \\
\text { Social Prevention; } \\
\text { The Department of Social } \\
\text { Care for Children; } \\
\text { Palacký University in } \\
\text { Olomouc }\end{array}$ & $\begin{array}{l}\text { medical specialists; } \\
\text { P-Center Association } \\
\text { [P-centrum, spolek]; } \\
\text { The House of Children } \\
\text { and Youth; } \\
\text { Department of Offences } \\
\text { - Municipal Office; } \\
\text { Police of the Czech } \\
\text { Republic; } \\
\text { Social Department } \\
\text { of the Municipal Office; } \\
\text { psychologists } \\
\text { and special pedagogues }\end{array}$ \\
\hline $\begin{array}{l}\text { Cooperation Between } \\
\text { School Prevention } \\
\text { Methodologist and } \\
\text { Education Consultant }\end{array}$ & $\begin{array}{l}\text { complementarity } \\
\text { and excellent } \\
\text { cooperation }\end{array}$ & rather exceptionally & almost none \\
\hline $\begin{array}{l}\text { Current Incidence } \\
\text { of Risk Behaviour }\end{array}$ & $\begin{array}{l}\text { rudeness; } \\
\text { vulgarity }\end{array}$ & $\begin{array}{l}\text { bullying; } \\
\text { cyberbullying }\end{array}$ & $\begin{array}{l}\text { aggression; } \\
\text { cigarettes, marijuana, } \\
\text { alcohol; } \\
\text { humiliation for social } \\
\text { differences }\end{array}$ \\
\hline
\end{tabular}

As evident from the above, none of the schools underestimate the prevention of risk behaviour. All schools use a number of teaching methods, trying to provide the pupils with more organizational forms of teaching so that the pupils are not the only passive recipients of information. Every school also uses their specific tools of feedback from the pupils. Therefore, the teachers have relevant information about how the pupils understand and evaluate the benefits of the activities linked to prevention. This can include activities related to the teaching of various school subjects which incorporate the topic of prevention, but they also include 
talks, lectures and excursions which are provided by institutions and experts working in the field of prevention.

\section{Conclusion}

On the basis of the research strategies, methods and techniques chosen, we have carried out a questionnaire survey, aimed at identifying the occurrence of specific types of manifestations of risk behaviour in selected primary schools of the Olomouc Region. An analysis was carried out of two important documents which are created by the individual schools and define the framework for the functioning of these schools, the prevention and protection of the health of the pupils from the manifestations of risk behaviour. We conducted a series of interviews with school prevention methodologists involved in the selected schools. In the context of the implementation of the milestone goals, we have obtained enough data to answer the questions we had formulated.

In their effort to protect the pupils from manifestations of risk behaviour, the schools use a variety of procedures. These can be divided into two categories: prevention and response. Through their prevention procedures, the schools try to prevent risk phenomena and situations that might endanger the pupils. Response procedures can be understood as those that are used for the solution of situations already incurred. Preventive action is de facto an informative educational process which highlights the topics connected with the risks. These specific topics require specific methods of teaching that are associated with and often arise from different organizational forms of teaching. The topics may be embedded into the usual school subjects, or introduced using specifically oriented programs. The subjects where the topic of prevention may be embedded include chemistry, science, history, language, literature, and civic and health education. In addition to these classical and steadily taught subjects, some items such as relaxation techniques against fatigue and stress, mental hygiene, or assertive behaviour, penetrate already the primary school subjects. The schools selected and examined by us use a similar spectrum of methods and organizational forms of teaching. The most widely used way of teaching is the frontal one when a teacher performs the exposition of the curriculum, operates in front of the pupils, addressing a single topic (the common teaching). The pupils have to concentrate and listen actively. This teaching uses the methods of interpretation and lecture. A variation can be seen in so-called peer programs where instead of the teacher, the pupils teach their peers who exercise certain collegiality, taking advantage of the minimum age gap from the listeners. Other variants are cooperative teaching and open learning where the pupils are given a greater degree of autonomy and accountability in the selection and implementation of activities related to teaching, utilizing mutual cooperation. The pupils participate in excursions and discussions led by experts working in the above mentioned specifically targeted programs. In all schools, the training of model situations can find its place. During these, the pupils are actively involved in the interpretation and based on improvisation, they play dramatic, topicoriented scenes or games, focused on, for example, coping with stress situations (refusal of offered drugs, of sex for money, etc.). Whether among the teachers or among the pupils, these are popular methods through which the pupils solve problems, using critical thinking. The 
method of discussion, using learning, discussion circles or community circles, finds its solid place in group-work. An interesting and not very usual method, used when working with the pupils of the older primary age, is the method of storytelling. Prevention efforts undertaken through the educational training process is not carried out only in ordinary and specialist classrooms. The schools themselves implement, facilitate or support the class events, school trips, ski and cycling courses, experiential lessons, gallery animations, concerts, team-building stays and tours. At the same time, they try to lead the pupils to active and meaningful fulfilment of free time through clubs, sports and physical activities. Sports, artistic, scientific activities are supported in a wide array so that no pupil is left without a choice of such use of free time. Also through these activities, the pupils develop their profiles in fields of their activity, taking part in pupils' competitions and Olympics. Their successes in turn has influence on the rest of their peers who may be positively motivated.

When it comes to the solution of the already incurred risk situations, there are minor differences among the schools which do not lie in the intentions and objectives, which are all the same, but in the procedures and methods of implementation. Two of the three schools have a crisis scenario that serves as aid for pedagogues who are concerned with current incidences and the prevention of their escalation. During these times, they more or less use the support and cooperation of the school prevention methodologists. Their practices can be summarized into three steps where the risk behaviour of a pupil is only solved on the premises of the school, between the pedagogical worker and the pupil. It is cooperation based on positive motivation and negotiation. The second step in the solution of risk behaviour is the involvement of legal representatives into the problem. The supervision of the pupil and the influence on his/her person are increasing but the cooperation is still based on negotiation and the use of positive motivation of the pupil. If the risk behaviour does not stop, the school can pass the matter to another party which is represented by specialised institutions. Since 2014, schools can use another tool which is a kind of extension of the normal agreement cooperation between the school and the legal representatives. This is the individual educational program (IEP), through which all three stakeholders commit to fulfilling the objectives and procedures for the prevention of further escalation of the development of the pupil's risk behaviour. Specific commitment arises which is drawn-up in the form of a written document. This tool has not been used by any of the schools.

In case of prevention activity, schools use specialized programs. These can be effectuated from their own resources but the more widespread way is their mediation by specialized experts and institutions, both public and private, who operate in the field of education and prevention. The training programs and education involves police officers of national, municipal or local units. Experts working at departments of municipal offices (Department of Social Prevention, Social Welfare Department, Social Department, the Department of Offences). Schools also invited specialists from various disciplines - curators, doctors, psychologists and special educators. The following organizations, active in the field of prevention and education, are mentioned: ACET Czech Republic - civic interest and professional association specialising in education on HIV/ AIDS and risk behaviour of the pupils; P-Center as an organization of social services active in the area of prevention of addictions and family care; the organization People in Need, PBC which implements education and raising awareness in the topics of poverty, human rights, xenophobia and racism. Educational programs of similar focus are also organized by ARPOK PBC dealing 
among other things with humanitarian aid and development cooperation, or Spolek D, an Association that provides consulting in the area of application of the clients' rights, services and interests. Interest, activating, and entertaining events of the The House of Children and Youth. When addressing the manifestations of risk behaviour, the schools cooperate with PPCFs and educational centres specifically across the region. The views of the methodologists on the creation of the Minimum Prevention Programs vary and each methodologist has a different understanding of the mission of the program. The methodologist working in Primary A does not understand the program as something significantly affecting the preventive action. According to him, this is not about drawn up procedures and plans, but about human relationships, the art of accustoming oneself with the pupils and having a positive impression on them. On the contrary, the Primary $\mathrm{C}$ methodologist understands the Minimum Prevention Program as an appropriate supplement for the curriculum and if it is handled with all the requisites, it fulfils the assumption that it will also fulfil its purpose well. The methodologist of Primary B also talks about the meaning of the annual creation of preventive program, but the whole concept could become simplified. The methodologists are mostly alone in processing the programs. Their fellow teachers at the most provide material for the school subjects where they themselves work and they comment on the final version of the program.

Spurný (2011) in his contribution in the Prevention Magazine talks about the sorry current practice of assigning these highly demanding positions to the inexperienced teachers. Methodologists who do not have a greater interest in the issue, are appointed in this specialized position against their will. In their activities - coordination, in particular - they are misunderstood and there is no participation on the part of other teachers and headmasters who see the prevention activities in schools only as the domain of the prevention methodologist. The author also mentions the controversies among headmasters he has witnessed. They were regarding the necessity of assigning the "position of the school methodologist" in their schools. According to some of the Directors, the whole concept of primary prevention is a bubble which becomes increasingly larger in size, which is, however, required "from above". Freely speaking, the mentioned headmasters argued that problems to be prevented have, on the contrary, been opened the door to, as the pupils learn information they previously had no idea about.

Skopal, Dolejš and Suchá also implemented a research in 2014 which focused on the personal traits and risk behaviour of Czech pupils. The research involved 4,198 participants aged 11-15 years, attending 54 educational establishments (more than $1.2 \%$ of the reference population). From the conclusions which the said researcher reached, it follows that in the reference population, $4 \%$ of respondents had been drunk in the last 30 days. If the result is projected to the entire population, it is approximately 14 thousand of adolescents aged 11-15 years who were drunk. In the same age category, there are more than $3 \%$ of the adolescents who smokes 5 and more cigarettes a day. This means a calculated equivalent of more than 10 thousand children. Ridicule or other injuries of this nature through social networks have been experienced in the last 30 days by up to $7 \%$ of the pupils, victims of physical aggression formed $12 \%$ and $12 \%$ of the respondents experienced verbal aggression. Damage to property of another was done by $15 \%$ of the respondents, and $7 \%$ had problems with the police. $25 \%$ of the adolescents have deliberately hurt themselves (Skopal, Dolejš and Suchá, 2014).

In connection with these warning signals, it is demonstrable, that prevention is and must be included in the training-educational activities. The objectivity of this topic is underlined by a number of 
students attending pedagogical and philosophical faculties, who chose this issue as the topic of their theses. ${ }^{8}$ The results of this research can be used by schools, for example, for the creation of their own documents aimed at the prevention of risk behaviour (the Minimum Prevention Programme, the school anti-bullying program, or a crisis scenario), because here they have a complete overview of risk phenomena, which occur in the classes at the second stage of primary schools. The work may also serve to improve the professional skills of future pedagogues and primary school pedagogues already in practice.

\section{References}

Act no. 561/2004 on Preschool, Basic, Secondary, Tertiary Professional and Other Education (the Education Act). [online]. Accessed $12^{\text {th }}$ November 2015. www.zakonyprolidi.cz/cs/2004-561.pdf.

Act no. 563/2004 on Pedagogical Staff and on the Amendment to Some Other Acts. [online]. Accessed $12^{\text {th }}$ November 2015. www.zakonyprolidi.cz/cs/2004-563.pdf.

Adámková, T. (2012). Př́stupy v primární prevenci. [Approaches in Primary Prevention]. In M. Miovský et al., Výkladový slovník základních pojmů školské prevence rizikového chování [Expository Dictionary of Basic Terms of Educational Prevention of Risk Behaviour] (pp. 121-125). Prague: Charles University in Prague \& Togga.

Binarová, I. (2008). Období dospívání, Období adolescence. [The Period of Maturing, The Period of Adolescence]. In J. Šimíčková-Čížková et al., Přehled vývojové psychologie [An Overview of Developmental Psychology] (pp. 101-118). Olomouc: Palacký University in Olomouc.

Broža, J. (2008). Děti a mladiství. [Children and Juveniles]. In K. Kalina et al., Základy klinické adiktologie [Fundamentals of Clinical Addictology] (pp. 253-262). Prague: Grada Publishing Inc.

Čapek, R. (2010). Tř́dní klima a školní klima. [The Classroom Climate and the Class Register]. Prague: Grada Publishing Inc.

Čech, T. (2012). Prevence. [Prevention]. In M. Miovský et al., Výkladový slovník základních pojmů školské prevence rizikového chování [Expository Dictionary of Basic Terms of Educational Prevention of Risk Behaviour] (pp. 107-112). Prague: Charles University in Prague \& Togga.

Černý, M. (2010).Základníúrovněprováděníprimárníprevence.[The Basic Level of Implementation of Primary Prevention]. In M. Miovský, L. Skácelová, J. Zapletalová, \& P. Novák et al. Primární prevence rizikového chování ve školství [Primary Prevention of Risk Behaviour in Education] (pp. 42-43). Prague: SCAN Association, Charles University in Prague \& Togga.

Decree no. 72/2005 on the Provision of Counselling Services in Schools and School Counselling Facilities. [online]. Accessed $11^{\text {st }}$ November 2015. www.zakonyprolidi.cz/cs/2005-72.pdf.

\footnotetext{
${ }^{\mathbf{8}}$ For example, in the information system of Masaryk University in Brno, there are 896 theses registered on the topic of risk behaviour and 873 theses dealing with primary prevention, all listed in June 2015.
} 
EURYPEDIA. European Encyclopedia on National Education Systems. (2015). Czech Republic. [online]. Accessed 24 $4^{\text {th }}$ September 2015. https://webgate.ec.europa.eu/fpfis/mwikis/eurydice/ index.php/Czech-Republic:Overview.

Grecmanová, H. (2008). Klima školy. [School Climate]. Olomouc: Hanex.

Kovářová, R., \& Zezulková, E. (2013). Speciálně pedagogická diagnostika v praxi. [Special Pedagogical Diagnostics in Practice]. [online]. Ostrava: University of Ostrava. Accessed $21^{\text {st }}$ September 2015. http://1url.cz/3OW0.

Kraus, B. (2008). Základy sociální pedagogiky. [Basics of Social Pedagogy]. Prague: Portál.

Kraus, B., \& Poláčková, V. et al. (2001). Člověk - prostředí - výchova. [Human - Environment Education]. Kotázkám sociální pedagogiky. [On the Issues of Social Pedagogy]. Brno: Paido.

Kupčík, O., \& Skopalová, J. (2014). Klima třídy na 2. stupni základních škol z hlediska projevů rizikového chování ve třídě. [The Class Climate at Second Stage of Primary Schools in View of Risk Behaviour in the Class]. In PHD EXISTENCE 2014: Česko-slovenská psychologická konference (nejen) pro doktorandy a o doktorandech [Czech-Slovak psychological Conference (not only) for Postgraduates and about Postgraduates]. [DVD]. Olomouc: Palacký University.

Lašek, J. (2001). Sociálně psychologické klima školních tříd a školy. [Socio-Psychological Climate of School Classes and Schools]. Hradec Králové: Gaudeamus.

Mareš, J., Průcha, J., \& Walterová, E. (2003). Pedagogický slovník. [Pedagogical Dictionary]. Prague: Portál.

Mertin, V. (2011). Individuální výchovný plan. [Individual educational plan]. [online presentation]. Accessed $2^{\text {nd }} \quad$ March 2015. www.zsrakovskeho.cz/files/media/individualni-vychovnyplan-4.4.2011.ppt.

MEYS of the Czech Republic. (2001). Strategie prevence sociálně patologických jevư u dětí a mládeže v pưsobnosti resortu Ministerstva školství, mládeže a tělovýchovy na období 2001-2004. [Strategy of the Prevention of Socially Pathological Phenomena Among Children and Youth in the Scope of the Ministry of Education, Youth and Sports for the Period 2001-2004]. [online]. Accessed $1^{\text {st }}$ November 2015. www.msmt.cz/file/736711/.

MEYS of the Czech Republic. (2005). Strategie prevence sociálně patologických jevů u dětí a mládeže v působnosti resortu Ministerstva školství, mládeže a tělovýchovy na období 2005-2008. [Strategy of the Prevention of Socially Pathological Phenomena Among Children and Youth in the Scope of the Ministry of Education, Youth and Sports for the Period 2005-2008]. [online]. Accessed $1^{\text {st }}$ November 2015. www.msmt.cz/file/7378_1_1/.

MEYS of the Czech Republic. (2007). Metodický pokyn k primární prevenci sociálně patologických jevů u détí, žáků a studentů ve školách a školských zařízeních (č.j. 20 006/2007-51 ze dne 16. 10. 2007). [Methodological Instruction of the Ministry of Education, Youth and Sports to the Primary Prevention of Socially Pathological Phenomena Among Children, Pupils and Students in Schools and Educational Establishments (no. 20 006/2007-51 from 16 $6^{\text {th }}$ October 2007)]. [online]. Accessed $1^{\text {st }}$ November 2015. www.msmt.cz/file/8602_1_1/. 
MEYS of the Czech Republic. (2010). Metodické doporučení Ministerstva školství, mládeže a tělovýchovy (dále jen MŠMT) k primární prevenci rizikového chování u dětí, žáků a studentů (dálejen “žák”) ve školách a školských zař́zeních (č.j. 21291/2010-28). [Methodological Recommendation for Primary Prevention of Risk Behaviour in Children, Pupils and Students in Schools and Educational Establishments (no. 21291/2010-28)]. [online]. Accessed $1^{\text {st }}$ November 2015. www.msmt.cz/ uploads/Metodickedoporuceniuvodnicast.doc.

MEYS of the Czech Republic. (2013). Metodický pokyn Ministerstva školství, mládeže a tělovýchovy $k$ řešení šikanování ve školách a školských zařízeních (č.j. 22294/2013-1). [Methodological Instruction of the Ministry of Education, Youth and Sports in Addressing Bullying in Schools and Educational Establishments (no. 22294/2013-1)]. [online]. Accessed $1^{\text {st }}$ November 2015. www.msmt.cz/uploads/Metodicky_pokyn_k_sikanovani.doc.

MEYS of the Czech Republic. (2013a). Národní strategie primární prevence rizikového chování dètí a mládeže na období 2013-2018. [National Strategy for Primary Prevention of Risk Behaviour of Children and the Youth for the Period 2013-2018]. [online]. Accessed $1^{\text {st }}$ November 2015. www. msmt.cz/file/20270.

Miovský, M. (2010). Historie a současné pojetí primární prevence rizikového chování v České republice. [The history and the current concept of primary prevention of risk behaviour in the Czech Republic]. In M. Miovský, L. Skácelová, J. Zapletalová, \& P. Novák et al., Primární prevence rizikového chování ve školství [Primary Prevention of Risk Behaviour in Education] (pp. 13-28). Prague: SCAN Association, Charles University in Prague \& Togga.

Miovský, M., Skácelová, L., Čabalová, L., Veselá, M., \& Zapletalová, J. (2012). Návrh doporučené struktury minimálního preventivního programu prevence rizikového chování pro základní školy. [The Design of Recommended Minimum Prevention Program Structure for the Prevention of Risk Behaviour for Primary School]. Prague: Charles University in Prague \& Togga.

National Institute for Education, school counselling facilities and facilities for further education of teaching staff, the PPCF and prevention. (2013). Souhrnná závěrečná zpráva z dvouletého pokusného ověrování Individuálního výchovného programu (smlouvy s rodiči) (pưvodně Individuální výchovný plán). [Two-Year Summary Final Report of the Experimental Verification of the Individual Educational Program (contract with parents) (Originally an Individual Educational Plan)]. [online]. Accessed 5 ${ }^{\text {th }}$ July 2015. www.msmt.cz/file/32875/.

National Institute for Education. (2013). Certifikační řád pro hodnocení odborné způsobilosti poskytovatelü programů školské primární prevence rizikového chování. [The Certification Procedure for the Evaluation of the Competence of Providers of Educational Programs of Primary Prevention of Risk Behaviour]. [online]. Accessed $10^{\text {th }}$ November 2015. www.nuv.cz/uploads/Certifikacni_rad_ web.doc.

Paulík, K. (2004). Vývojová psychologie pro doplňující pedagogické studium. [Developmental Psychology for Supplementary Pedagogical Studies]. [online]. Ostrava: University of Ostrava, Pedagogical Faculty, Centre for Life-Long Education. Accessed $5^{\text {th }}$ August 2015. www.osu.cz/fpd/ cdv/dokumenty/vyvojova_psychologie.pdf. 
Petrová, A., \& Plevová, I. (2012). Obecná psychologie. [General Psychology]. [online]. Olomouc: Palacký University in Olomouc, Pedagogical Faculty. Accessed $2^{\text {nd }}$ March 2015. www.pdf.psych. upol.cz/files/soubory/studijni-materialy/plevova-petrova-obecna-psych.pdf.

Prevence rizikového chování. [Prevention of Risk Behaviour]. [online]. Accessed $5^{\text {th }}$ August 2015. www.prevence-info.cz/r-rizikove-chovani.

Průcha, J. (2005). Česká pedagogická věda v současnosti: Pokus o pozitivní reflexi stavu. [Czech Pedagogical Science at Present: An Attempt at Positive Reflection of the Status]. Pedagogika, 55(3), pp. 230-247.

Širůčková, M. (2012). Rizikové chování. [Risk Behaviour]. In M. Miovský et al., Výkladový slovník základních pojmů školské prevence rizikového chování [Expository Dictionary of Basic Terms of Educational Prevention of Risk Behaviour] (pp. 127-132) Prague: Charles University in Prague \& Togga.

Skácelová, L. (2003). Osobnost, dovednosti a techniky v primární prevenci. [The Personality, Skills and Techniques in Primary Prevention]. In K. Kalina, Drogy a drogové závislosti [Drugs and Drug Addiction] (pp. 329-332). Prague: The Government Office of the Czech Republic.

Skácelová, L. (2010). Doporučené postupy a rady v modelových situacích pro oblast záškoláctví. [Recommended Practices and Tips in Model Situations for Truancy]. In M. Miovský, L. Skácelová, J. Zapletalová, \& P. Novák et al., Primární prevence rizikového chování ve školství [Primary Prevention of Risk Behaviour in Education] (pp. 183-189). Prague: SCAN Association, Charles University in Prague \& Togga.

Skácelová, L. (2012). Metody v primární prevenci. [Methods in Primary Prevention]. In M. Miovský et al., Výkladový slovník základních pojmů školské prevence rizikového chování [Expository Dictionary of Basic Terms of Educational Prevention of Risk Behaviour] (pp. 93-97). Prague: Charles University in Prague \& Togga.

Skopal, O., Dolejš, M., \& Suchá, J. (2014). Vybrané osobnostní rysy a rizikové formy chování u českých žáků a žákyn̆. [Selected Personality Traits and Forms of Risk Behaviour in Czech Pupils]. [online]. Olomouc: Palacký University in Olomouc, Philosophical Faculty. Accessed $18^{\text {th }}$ May 2015. http://1url.cz/u5CQ.

Spurný, L. (2011). Zbytečný odborník anebo děvečka pro všechno?! [Unnecessary Expert or Maid-ofAll-Work?!] Aneb pár slov o tom, kým by určitě neměl být školní metodik prevence... [Or a Few Words on Who a School Prevention Methodologist Definitely Should Not Be]. Prevence, 8(4), pp. 10-11.

Štech, S. (2010). Školní socializace, disciplinace a prevence rizikového chování. [School socialization, disciplinace and prevention of risk behaviour]. In M. Miovský, L. Skácelová, J. Zapletalová, \& P. Novák et al., Primární prevence rizikového chování ve školství [Primary Prevention of Risk Behaviour in Education] (pp. 145-152). Prague: SCAN Association, Charles University in Prague \& Togga.

Sýkora, P. (2010). Prevence drogových závislostí: kvalitní výchova v rodině. [Prevention of Drug Addiction: Quality Family Upbringing]. In M. Machalová et al., Dialógy o závislostech [Dialogues on Addiction] (pp. 41-61). Bratislava: TakeOff Advertising., Ltd. 
Team of Authors. (2006). Rámcový vzdělávací program pro základní vzdělávání - př́loha upravující vzdělávání žáků s lehkým mentálním postižením. [Core Curriculum Program for Primary Education - Annex Governing the Education of Pupils with Slight Mental Disabilities]. [online]. Accessed $1^{\text {st }}$ August 2015. www.msmt.cz/file/10429_1_1/download/.

\section{Authors}

Mgr. Lucie Blaštíková

Pedagogical Faculty, Palacký University in Olomouc

Department of Pedagogy and Social Studies

Žižkovo nám. 5, 771 40, Olomouc, Czech Republic

lucka.blastikova@seznam.cz

doc. PhDr. Jitka Skopalová, Ph.D.

Faculty of Public Policies, Silesian University in Opava

The Institute of Pedagogical and Psychological Sciences

Bezručovo náměstí 885/14, 746 01, Opava, Czech Republic

jitka.skopalova@fvp.slu.cz

Mgr. et Mgr. Jan Zelinka

Social Services Centre

Bratří Čapků 662, 783 91, Uničov, Czech Republic

zelijan@seznam.cz 